\title{
Possibility of Injecting Adipose-Derived Stromal Vascular Fraction Cells to Accelerate Microcirculation in Ischemic Diabetic Feet: A Pilot Study
}

\author{
Kyung-Chul Moon, Ha-Yoon Chung, Seung-Kyu Han, Seong-Ho Jeong, Eun-Sang Dhong \\ Department of Plastic Surgery, Korea University Guro Hospital, Seoul, Korea
}

\begin{abstract}
Background and Objectives: Beneficial effects of human adipose-derived stromal vascular fraction (SVF) cell injection on microcirculation have been recently reported in in vitro and in vivo studies. However, no clinical studies have reported its effect in diabetic patients who commonly experience compromised tissue perfusion, regardless of the status of intravascular blood flow. The present piloting study was designed to clinically examine the possibility of SVF cell injection to accelerate microcirculation, particularly in ischemic diabetic feet.

Methods: Ten diabetic feet were included to receive subcutaneous injection of SVF cells around wounds. Transcutaneous partial oxygen pressure $\left(\mathrm{TcPO}_{2}\right)$ and cutaneous microvascular blood flow were measured before and every four weeks after cell injection until the $12^{\text {th }}$ week visit.

Results: $\mathrm{TcPO}_{2}$ values increased from $31.3 \pm 7.4$ before injection to $46.4 \pm 8.2 \mathrm{mmHg}$ at 12 weeks after SVF injection (1.5-fold, $\mathrm{p}<0.05$ ). Cutaneous microvascular blood flow levels increased from $34.0 \pm 21.1$ before injection to $76.1 \pm 32.5$ perfusion unit at 12 weeks after SVF injection $(2.2$-fold, $\mathrm{p}<0.05$ ). There were no adverse events related to SVF cell injection.

Conclusions: Results of this study demonstrate that adipose-derived SVF cell injection have the possibility to provide beneficial effects on microcirculation in ischemic diabetic feet.
\end{abstract}

Keywords: Diabetic foot, Microcirculation, Stromal vascular fraction cell, Tissue oxygenation

\section{Introduction}

The importance of blood flow and oxygen delivery to wound bed cannot be overstated for successful wound

Received: October 26, 2018, Revised: January 4, 2019,

Accepted: January 14, 2019, Published online: February 28, 2019

Correspondence to Seung-Kyu Han

Department of Plastic Surgery, Korea University Guro Hospital,

148 Guro-dong, Guro-gu, Seoul 08308, Korea

Tel: +82-2-2626-3333, Fax: +82-2-868-6698

E-mail: pshan@kumc.or.kr

(c) This is an open-access article distributed under the terms of the Creative Commons Attribution Non-Commercial License (http://creativecommons.org/ licenses/by-nc/4.0/), which permits unrestricted non-commercial use, distribution, and reproduction in any medium, provided the original work is properly cited.

Copyright (c) 2019 by the Korean Society for Stem Cell Research healing in diabetic patients. Therefore, standard revascularization methods such as percutaneous transluminal angioplasty (PTA) and vascular bypass graft have been performed to improve blood flow and tissue oxygenation in diabetic feet $(1,2)$. However, diabetic patients may not be eligible for these methods due to the presence of high- risk co-morbidities (3). Furthermore, the therapeutic effect of standard revascularization methods may not be sufficient to improve distally located arterial occlusion in diabetic feet.

Previous studies have shown that mesenchymal stem cell (MSC) injection may hold great promise for improving microcirculation in critical limb ischemia (4-6). Bone marrow stroma has been a main source of MSCs. A previous in vitro study performed by our group has demonstrated that bone marrow-derived MSCs (BM-MSCs) pro- 
duced significantly higher amounts of vascular endothelial growth factor (VEGF) than dermal fibroblasts (7). Furthermore, they showed greater activity in terms of angiogenesis in vivo, indicating their potential use for accelerating microcirculation. However, the procurement is relatively invasive. It may increase the risk of infection (8). In addition, it has become difficult for a clinician to use cultured BM-MSCs due to issues related to approval by the Food and Drug Administration (FDA).

Meanwhile, human adipose-derived stromal vascular fraction (SVF) cells have been demonstrated as one of sources of MSCs $(9,10)$. SVF cells, which could be obtained in large quantities without cell culture, contain heterogeneous cell populations, including stem cells and endothelial cells known to accelerate angiogenesis. Recently, beneficial effects of SVF cell injection on microcirculation have been reported in in vitro and in vivo studies (11-14). However, no clinical studies reported the effect of SVF cell injection on microcirculation in diabetic patients who commonly experience compromised tissue perfusion regardless of the status of the intravascular blood flow.

The purpose of this pilot study was to examine the possibility of injecting SVF cells to accelerate cutaneous microcirculation in ischemic diabetic feet, in which tissue perfusion could not be improved enough for wound healing even after revascularization.

\section{Patients and Methods}

This study protocol was approved by the Institutional Review Board of Korea University Guro Hospital (approval number: 2017GR0756). Written informed consent was obtained from each patient included in this study. This study was performed in full accordance with the principles of the Declaration of Helsinki.

\section{Patients}

The major inclusion criteria were: type 1 or type 2 diabetes diagnosed by diabetologists according to the criteria of the American Diabetes Association. Patients with foot ulcers and significant lower extremity ischemia as defined by a $\mathrm{TcPO}_{2}<40 \mathrm{mmHg}$ even after patients underwent PTA or inability to tolerate PTA due to presence of high-risk co-morbidities were included. Patients were excluded if they had any infection, osteomyelitis, or other disorder such as deep venous thrombosis, rheumatoid arthritis, systematic lupus erythematosus, or any other systematic inflammatory disease that could interfere with microcirculation. Patients were also excluded if they had poor prognosis diseases including malignant tumors or if they were being treated with corticosteroids, immunosuppressive drugs, or chemotherapy. Those who had prior or ongoing treatments with any cells in the past 4 weeks were also excluded.

This study included 10 patients (6 males and 4 females) with a mean age of $66.1 \pm 15.3$ years (range, 33 to 84 years) who were treated at the Diabetic Wound Center of Korea University Guro Hospital between November 2017 and March 2018. One patient was lost to follow-up during the study period. Therefore, assessment was conducted for available data from the remaining 9 patients who completed this study (Table 1).

\section{Autologous SVF cell preparation}

Abdominal adipose tissues were obtained from patients by liposuction under local anesthesia. After a small stab incision was made in the umbilicus, local anesthetic solution was infiltrated using a blunt Lamis infiltration cannula. The local anesthetic solution consisted of $2 \%$ lidocaine with $1: 200,000$ epinephrine. The amount of solution infiltrated was generally twice the amount of adipose tissue predicted to be obtained in the procedure. Adipose tissues were aspirated using a $50-\mathrm{ml}$ syringe attached to a cannula with a 3-mm inner diameter, designed to be large enough to harvest intact adipose tissue parcels. The plunger of the 50-ml syringe was pulled back during aspiration, so as not to create too much negative pressure that would result in adipose tissue rupture. After harvesting adipose tissues, the incision was closed with interrupted nylon sutures.

The average amount of aspirated adipose tissue was $38.5 \pm 4.9 \mathrm{ml}$ (range, 30 to $46 \mathrm{ml}$ ). The adipose tissue was processed for autologous SVF cell isolation using an automated SVF isolation device system (Cellunit; CGBio Inc.,

Table 1. Demographic and wound characteristics of patients who underwent SVF cell injection at baseline

\begin{tabular}{ccclcc}
\hline \multirow{2}{*}{$\begin{array}{c}\text { Patient } \\
\text { No. }\end{array}$} & $\begin{array}{c}\text { Age/ } \\
\text { Gender }\end{array}$ & \begin{tabular}{c} 
Area \\
\cline { 3 - 6 }$\left(\mathrm{cm}^{2}\right)$
\end{tabular} & Location & $\begin{array}{c}\text { Wagner } \\
\text { grade }\end{array}$ & $\begin{array}{c}\text { Duration } \\
(\text { month) }\end{array}$ \\
\hline 1 & $73 / \mathrm{M}$ & 9 & Right/Plantar & II & 3 \\
2 & $57 / \mathrm{M}$ & 12 & Right/Border & I & 48 \\
3 & $56 / \mathrm{M}$ & 30 & Left/Dorsal & II & 2 \\
4 & $84 / \mathrm{M}$ & 10 & Left/Dorsal & II & 6 \\
5 & $75 / \mathrm{F}$ & 6 & Right/Dorsal & II & 1 \\
6 & $33 / \mathrm{M}$ & 25 & Right/Dorsal & II & 1 \\
7 & $71 / \mathrm{F}$ & 22 & Left/Border & II & 6 \\
8 & $76 / \mathrm{F}$ & 17 & Right/Dorsal & II & 6 \\
9 & $57 / \mathrm{F}$ & 48 & Left/Border & II & 2 \\
\hline
\end{tabular}


Seongnam, Gyeonggi-do). This automated SVF isolation system consisted of a device and sterile disposable cartridges for tissue digestion, washing, and waste collection. Briefly, obtained samples were enzymatically digested with $0.1 \%$ collagenase (SERVA Electrophoresis $\mathrm{GmbH}$, Heidelberg, Germany) in a processing chamber. These samples were washed with saline to remove collagenase and centrifuged to obtain SVF cells. SVF cells were collected within 50 minutes. These collected SVF cells were aspirated from a processing canister immediately prior to injection (Fig. 1). The total cell number and nucleated SVF cells were determined by using an automated cell counter (Luna-FL ${ }^{\mathrm{TM}}$; Logos Biosystems, Anyang). The total amount of injected SVF cell suspension was 3.6 \pm $0.2 \times 10^{7}$ cells (range, 1.7 to $6.7 \times 10^{7}$ cells) at a final concentration of $9.6 \pm 4.2 \times 10^{5}$ cells $/ \mathrm{ml}$ (range, 4.8 to $16.8 \times 10^{5}$ cells $/ \mathrm{ml}$ ). The cell viability of isolated SVF cells was $89.4 \pm 3.6 \%$ (range, 80.9 to $94.3 \%$ ).

\section{SVF cell injection}

Treatment was performed as an outpatient care procedure with local anesthesia. After preparing the skin around the wound with an antiseptic, SVF cell suspension was injected into subcutaneous layers around the wound,
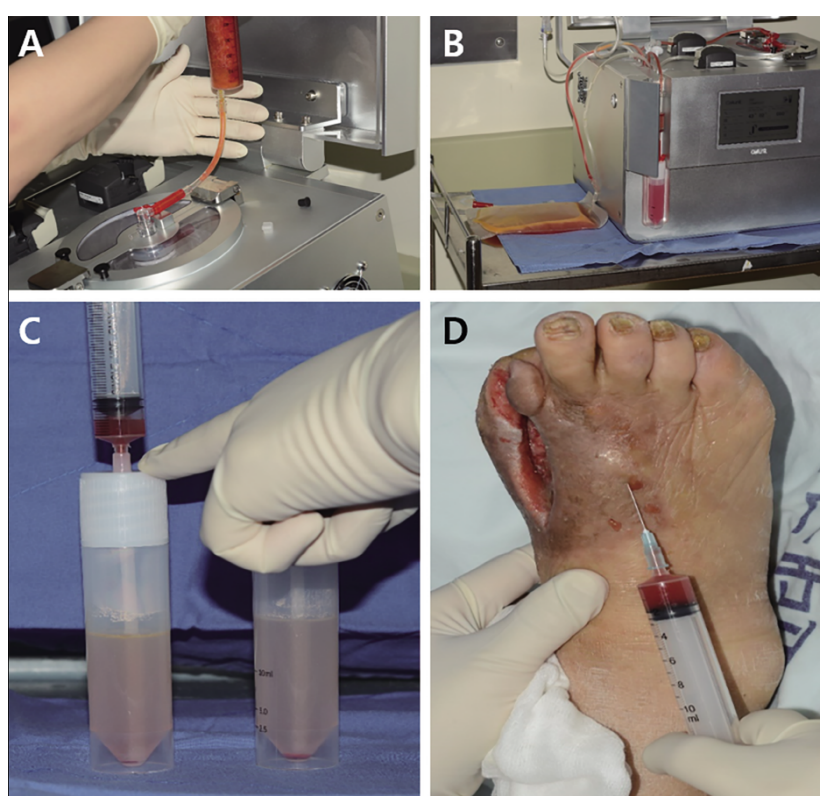

Fig. 1. SVF cell isolation and injection. (A) The aspirated adipose tissue was prepared and introduced into a processing chamber with a single-use sterile disposable set. (B) SVF cells were collected in a processing canister. (C) SVF cells in the canister were aspirated using a 10-cc syringe immediately prior to injection and (D) injected into subcutaneous layers around the diabetic wound using a 23-gauge needle. approximately $2 \mathrm{~cm}$ from the margin of the wound via a retrograde threading technique (Fig. 1). Since the number of obtained cells was limited, and we wanted to transplant as many cells as possible, all SVF cells were injected without dose standardization. The total mean volume of SVF cells for injection was $2.1 \pm 0.4 \mathrm{ml}$ (range, 1.8 to $2.7 \mathrm{ml}$ ). The administered dose of the SVF cell suspension was approximately $0.3 \mathrm{ml}$ per injection and the number of injections largely depended on the wound size. Therefore, SVF cells were generally injected at six to ten points around the wound. These cells were injected in one session.

The wound and the injection sites were covered with a polyurethane foam (Mepilex; Molnlycke Health Care, Gothenburg, Sweden). Concomitant biological and biochemical therapy including growth factors were not allowed.

\section{Measurement of $\mathrm{TcPO}_{2}$}

$\mathrm{TcPO}_{2}$ of the foot was measured before and every four weeks after cell injection until the $12^{\text {th }}$ week visit. $\mathrm{TcPO}_{2}$ values were measured using a $\mathrm{PF} 5040 \quad \mathrm{TcPO}_{2}$ unit (PeriFlux System 5040; Perimed AB, Stockholm, Sweden) and PeriSoft software (PeriSoft for Windows 2.50; Perimed $\mathrm{AB}$ ). A $\mathrm{TcPO}_{2}$ sensor was fixed on the dorsum of each foot in the tarsometatarsal area of the first intermetatarsal space. Because $\mathrm{TcPO}_{2}$ measurements could be affected by multiple extrinsic factors, we sought to minimize these factors during this study. $\mathrm{TcPO}_{2}$ measurements for all patients were performed by a single expert to maintain consistency. Room temperature was maintained from 25 to $26^{\circ} \mathrm{C}$ during the study period. The skin was heated at an electrode temperature of $43^{\circ} \mathrm{C}$. To test $\mathrm{O}_{2}$ leakage, we sprayed oxygen around the sensor site for several seconds and confirmed that the reading on the monitor did not increase quickly. To obtain stable reading, we waited for 10 to 15 minutes before measuring $\mathrm{TcPO}_{2}$ values.

\section{Measurement of cutaneous microvascular blood flow}

One hour after $\mathrm{TcPO}_{2}$ measurement, cutaneous microvascular blood flow was recorded in the same location and environment as $\mathrm{TcPO}_{2}$ measurement by Laser Doppler flowmetry (LDF; PeriFlux System 5010, Perimed AB). The LDF probe was gently applied to each testing site using an adhesive pad to avoid vascular compression. Caution was taken to minimize external disturbance and movement. Continuous measurements were made for five minutes at each measuring sites. Averaged data obtained in the last one minute were recorded. 


\section{Evaluation}

Efficacy was assessed using primary and secondary efficacy criteria. Primary efficacy criterion was $\mathrm{TcPO}_{2}$ value change from baseline to that at the $12^{\text {th }}$ week visit. Secondary efficacy criteria were $\mathrm{TcPO}_{2}$ value changes from baseline to that at the $4^{\text {th }}$ and $8^{\text {th }}$ week visits and those of cutaneous microvascular blood flow level changes from baseline to that at the $4^{\text {th }}, 8^{\text {th }}$, and $12^{\text {th }}$ week visits.

For safety study, information on adverse event such as erythema and allergic reaction, adverse drug reaction, serious adverse event, and serious adverse drug reaction was collected at each visit. Safety was also monitored at indicated time points by evaluating laboratory findings and vital signs.

\section{Statistical analyses}

All data are expressed as mean \pm standard deviation. Wilcoxon rank-sum test was used to evaluate the improvement rate of $\mathrm{TcPO}_{2}$ values and LDF levels from baseline. A p-value $<0.05$ was considered statistically significant. All statistical analyses were performed using SPSS for Windows version 12.0 (SPSS, Inc., Chicago, IL, USA).

Table 2. Results of $\mathrm{TcPO}_{2}$ values at baseline and 4, 8, 12 weeks after SVF cell injection

\begin{tabular}{ccccc}
\hline Patient No. & $\begin{array}{c}\text { Baseline } \\
(\mathrm{mmHg})\end{array}$ & $\begin{array}{c}4 \text { weeks } \\
(\mathrm{mmHg})\end{array}$ & $\begin{array}{c}8 \text { weeks } \\
(\mathrm{mmHg})\end{array}$ & $\begin{array}{c}12 \text { weeks } \\
(\mathrm{mmHg})\end{array}$ \\
\hline 1 & 36 & 53 & 50 & 53 \\
2 & 37 & 51 & 43 & 44 \\
3 & 24 & 55 & 49 & 60 \\
4 & 39 & 42 & 36 & 34 \\
5 & 25 & 35 & 50 & 55 \\
6 & 39 & 49 & 44 & 45 \\
7 & 20 & 44 & 29 & 46 \\
8 & 26 & 46 & 42 & 40 \\
9 & 36 & 48 & 50 & 41 \\
Mean \pm SD & $31.3 \pm 7.4$ & $47.0 \pm 6.1$ & $43.7 \pm 7.2$ & $46.4 \pm 8.2$ \\
\hline
\end{tabular}

SD: standard deviation.

\section{Results}

Before SVF cell injection, the mean $\mathrm{TcPO}_{2}$ value was $31.3 \pm 7.4 \mathrm{mmHg}$. $\mathrm{TcPO}_{2}$ values increased to $46.4 \pm 8.2$ $\mathrm{mmHg}$ at 12 weeks after SVF cell injection $(\mathrm{p}=0.012)$. In results of secondary efficacy criteria, $\mathrm{TcPO}_{2}$ values at the $4^{\text {th }}$ and $8^{\text {th }}$ weeks after SVF cell injection were $47.0 \pm 6.1$ $\mathrm{mmHg}$ and $43.7 \pm 7.2 \mathrm{mmHg}$, respectively $(\mathrm{p}=0.004$ and $\mathrm{p}=0.008$ ). Every measured $\mathrm{TcPO}_{2}$ value after SVF cell injection was significantly improved compared to that at baseline (Fig. 2 and Table 2).

Before SVF cell injection, the mean cutaneous microvascular blood flow level measured by the LDF (perfusion unit, PU) was $34.0 \pm 21.1 \mathrm{PU}$. These levels at the $4^{\text {th }}, 8^{\text {th }}$, and $12^{\text {th }}$ weeks after SVF cell injection were $47.8 \pm 54.7$ PU, 44.4 $\pm 29.0 \mathrm{PU}$, and $76.1 \pm 32.5 \mathrm{PU}$, respectively. The highest measured microvascular blood flow level was observed at the $12^{\text {th }}$ week after SVF cell injection $(\mathrm{p}=0.004)$. However, there were no statistically significant differences between baseline level and levels at the $4^{\text {th }}$ or $8^{\text {th }}$ week after SVF cell injection (Fig. 2 and Table 3).

There was no adverse event, adverse drug reaction, seri-

Table 3. Results of cutaneous microvascular blood flow levels measured by Laser Doppler flowmetry at baseline and 4, 8, and 12 weeks after SVF cell injection

\begin{tabular}{ccccc}
\hline Patient No. & $\begin{array}{c}\text { Baseline } \\
(\mathrm{PU})\end{array}$ & $\begin{array}{c}4 \text { weeks } \\
(\mathrm{PU})\end{array}$ & $\begin{array}{c}8 \text { weeks } \\
(\mathrm{PU})\end{array}$ & $\begin{array}{c}12 \text { weeks } \\
(\mathrm{PU})\end{array}$ \\
\hline 1 & 25 & 47 & 26 & 78 \\
2 & 36 & 13 & 25 & 68 \\
3 & 48 & 177 & 58 & 136 \\
4 & 7 & 20 & 14 & 26 \\
5 & 39 & 25 & 30 & 69 \\
6 & 6 & 20 & 14 & 47 \\
7 & 68 & 93 & 77 & 81 \\
8 & 55 & 10 & 63 & 68 \\
9 & 22 & 25 & 93 & 112 \\
Mean \pm SD & $34.0 \pm 21.1$ & $47.8 \pm 54.7$ & $44.4 \pm 29.0$ & $76.1 \pm 32.5$ \\
\hline
\end{tabular}

SD: standard deviation, PU: perfusion unit.

\section{TcPO2}

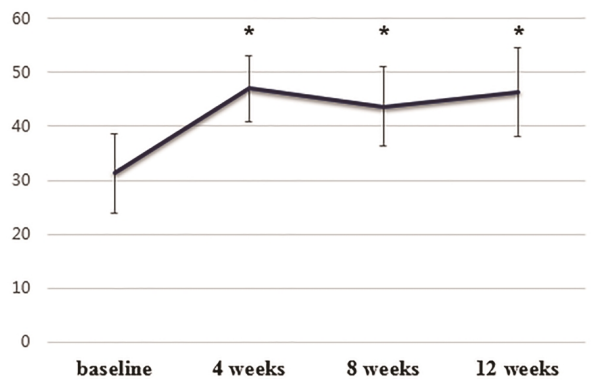

Microvascular Blood Flow

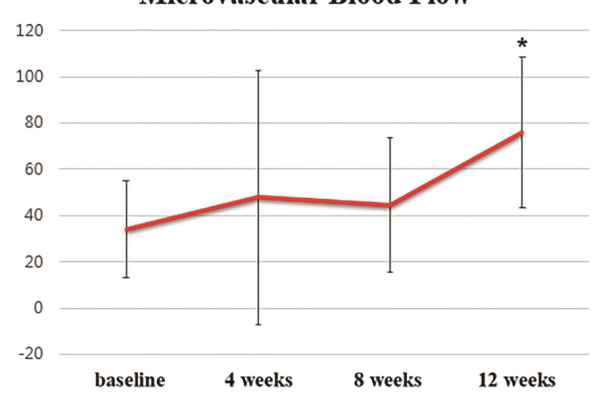

Fig. 2. Sequential values of $\mathrm{TcPO}_{2}$ and cutaneous microvascular blood flow $\left({ }^{*} p<0.05\right)$. 
ous adverse event, or serious adverse drug reaction related to study cells. Compared to baseline data, clinically meaningful changes for clinical and laboratory parameters including serum chemistry, hematology, urinalysis, and vital signs were not observed in any of these patients.

\section{Discussion}

The potential of stem cells has been explored to overcome limitations of conventional revascularization methods such as PTA and bypass surgery $(4,5,9)$. SVF cells consist of a heterogeneous population of cells, including adipose stromal, hematopoietic stem, progenitor, and endothelial cells (15). Our previous study has shown that vascular structures were newly formed after SVF cell injection in vivo (16). Costa et al. (17) have also reported that SVF cells may promote functional vascularization. Jin et al. (13) have compared angiogenic properties of SVF cells with those of adipose-derived stem cells (ASCs) in vivo and found that SVF cells had more therapeutic effects on hind limb ischemia via robust angiogenic and vasculogenic activity than ASCs. However, these results were from in vitro or in vivo studies. The present study might be the first report demonstrating the possibility of injecting SVF cells to accelerate microcirculation in ischemic diabetic feet.

A variety of methods are available to evaluate peripheral vascular status, including computed tomography angiography, subtraction angiography, and Doppler probing (18, 19). However, diabetic patients commonly experience compromised tissue perfusion, regardless of status of the intravascular blood flow (18, 20-22). Therefore, accurate quantitative assessment of tissue perfusion is important to predict wound healing. In this study, $\mathrm{TcPO}_{2}$ was evaluated along with microvascular blood flow.

This study demonstrated that tissue oxygenation increased significantly in response to SVF cell injection as determined by change in $\mathrm{TcPO}_{2}$, with values $48 \%$ greater than pre-treatment at the $12^{\text {th }}$ week after injection. The proportion of patients achieving increasing $\mathrm{TcPO}_{2}$ value at the $12^{\text {th }}$ week was $89 \%$. In addition, $\mathrm{TcPO}_{2}$ values of all patients in this study were below $40 \mathrm{mmHg}(31.3 \pm 7.4$ $\mathrm{mmHg}$ ) before SVF cell injection. These values increased to $46.4 \pm 8.2 \mathrm{mmHg}$ at 12 weeks after SVF cell injection. A $\mathrm{TcPO}_{2}>40 \mathrm{mmHg}$ is considered to be sufficient for wound healing, although there is some debate on the most appropriate threshold level necessary for wound healing (23). Wound healing is generally considered to be impossible when $\mathrm{TcPO}_{2}$ is below $20 \mathrm{mmHg}$ and impaired when levels are below $40 \mathrm{mmHg}$ (24). After SVF cell injection, the $\mathrm{TcPO}_{2}$ value increased to be over $40 \mathrm{mmHg}$ which is sufficient for wound healing. Results of this study also demonstrated that cutaneous microvascular blood flow level was significantly increased after SVF cell injection. The proportion of patients achieving increasing cutaneous microvascular blood flow level at the $12^{\text {th }}$ week was $100 \%$. These results suggest that SVF cell injection may have potential to improve microcirculation.

Interestingly, the peak value of $\mathrm{TcPO}_{2}$ was observed at 4 weeks after SVF cell injection and maintained until 12 weeks. The level of cutaneous microvascular blood flow was also increased at 4 weeks after cell injection, although the peak level was detected at the $12^{\text {th }}$ week. The reason for this delay in the maximal improvement of cutaneous microvascular blood flow is not well understood yet. In a previous study, angiogenesis was observed at a very early stage after SVF cell grafting (11). Jin et al. (13) have demonstrated that Matrigel plugs containing SVF cells were filled with blood cells after 2 weeks. Therefore, the $\mathrm{TcPO}_{2}$ value may increase at 4 weeks after SVF cell injection along with angiogenesis. However, results of LDF are derived by multiplying blood velocity by the concentration of red blood cells. Although there is a physiologic increase in perfusion, delay in dilatation of precapillary sphincters for freely entering red blood cells may reveal a discrepancy between results of $\mathrm{TcPO}_{2}$ value and cutaneous microvascular blood flow level.

Angiogenesis is a vital component of accelerating microcirculation in ischemic diabetic feet $(25,26)$. Angiogenesis, a biological mechanism for formation of new capillaries, is necessary to sustain newly-formed granulation tissues and for the survival of keratinocytes. SVF cells may stimulate endothelial cells to increase angiogenesis surrounding injection sites and the increased level of angiogenesis may vary depending on the injection sites and the number of injections. Wound beds, or the margin of the wound in ischemic diabetic feet may not have enough endothelial cells to accelerate microcirculation due to bacterial ingrowth and chronic inflammatory environment. Therefore, SVF cells were injected approximately $2 \mathrm{~cm}$ from the margin of the wound rather than adjacent to the wound in this study. Furthermore, SVF cells were all injected without dose standardization because the focus of this piloting study was to demonstrate whether microcirculation could be accelerated simply by injecting SVF cells in ischemic diabetic feet. Therefore, further studies based on detailed data regarding injection sites and the number of injections may be required to determine more precisely the effect of SVF cell injections on accelerating microcirculation in ischemic diabetic feet. 
The route of injection may also be an important factor for increasing microcirculation. A few clinical studies have demonstrated that ASCs administered through intra-arterial and intramuscular injection could increase microvascular supply in patients with critical limb ischemia $(27,28)$. However, intra-arterial injection of SVF cells may induce microembolisms (14). Narrowing or blocking the lumen of terminal arterioles due to microembolism may result in no-flow in corresponding capillaries. Intra-arterial delivery of SVF cells also poses risk of bubble formation (29). Therefore, subcutaneous injection of SVF cells may be an appropriate route for ischemic diabetic feet. To the best of our knowledge, this is the first study to demonstrate that subcutaneous injection of SVF cells may increase tissue oxygenation and cutaneous microvascular blood flow in ischemic diabetic feet.

The exact mechanism involved in the effect of SVF cells on accelerating microcirculation remains unknown. Direct injection of adipose-derived SVF cells into ischemic diabetic tissue might support the formation of new blood vessels in the target tissue. Recent studies have suggested that the action of SVF cells is to stimulate new blood vessel formation from pre-existing vessels $(12,30)$. Thus, SVF cells may provide a source of paracrine factors. SVF cells might be able to exert their effects by releasing various growth factors such as VEGF, hepatocyte growth factor, angiopoietin-1, interleukin-8, platelet-derived growth factor, and insulin-like growth factor to promote angiogenesis (13). In addition, endothelial precursor cells in SVF cells and correspondingly platelet-derived growth factors-BB produced by endothelial precursor cells may enable SVF cells to increase vasculature-like structure (31).

A limitation of the present study is that there is no control group arm. Our group has previously confirmed that $\mathrm{TcPO}_{2}$ value and cutaneous microvascular blood flow level were not significantly changed in diabetic foot patients at the $12^{\text {th }}$ week in an unpublished study. Thus, we did not include an untreated group arm in this preliminary study. As a pilot preliminary study to examine the possibility of injecting SVF cells to increase microcirculation in diabetic feet, we would like to advocate that the present study demonstrated promising results. Further studies will be followed with a larger sample size of patients and a longer follow-up to establish the effect of SVF cell injection with certainty. Comparison with a well-designed control group may accurately determine the efficacy of such treatment. Results of the present preliminary study demonstrate that adipose-derived SVF cell injection have the possibility to provide beneficial effects on microcirculation in ischemic diabetic feet. Ultimate efficacy of this treatment needs to be determined by further well-designed studies.

\section{Acknowledgments}

This research was supported by a researcher grant for clinical studies from CG Bio Inc. (Seongnam, Gyeonggido).

\section{Potential Conflict of Interest}

The authors have no conflicting financial interest.

\section{References}

1. Söderström MI, Arvela EM, Korhonen M, Halmesmäki KH, Albäck AN, Biancari F, Lepäntalo MJ, Venermo MA. Infrapopliteal percutaneous transluminal angioplasty versus bypass surgery as first-line strategies in critical leg ischemia: a propensity score analysis. Ann Surg 2010;252: 765-773

2. Kim HR, Han SK, Rha SW, Kim HS, Kim WK. Effect of percutaneous transluminal angioplasty on tissue oxygenation in ischemic diabetic feet. Wound Repair Regen 2011; 19:19-24

3. Collinson DJ, Donnelly R. Therapeutic angiogenesis in peripheral arterial disease: can biotechnology produce an effective collateral circulation? Eur J Vasc Endovasc Surg 2004;28:9-23

4. Xie B, Luo H, Zhang Y, Wang Q, Zhou C, Xu D. Autologous stem cell therapy in critical limb ischemia: a meta-analysis of randomized controlled trials. Stem Cells Int 2018;2018. doi: 10.1155/2018/7528464

5. Samura M, Hosoyama T, Takeuchi Y, Ueno K, Morikage $\mathrm{N}$, Hamano K. Therapeutic strategies for cell-based neovascularization in critical limb ischemia. J Transl Med 2017;15:49

6. Bateman ME, Strong AL, Gimble JM, Bunnell BA. Concise review: using fat to fight disease: a systematic review of nonhomologous adipose-derived stromal/stem cell therapies. Stem Cells 2018;36:1311-1328

7. Han SK, Chun KW, Gye MS, Kim WK. The effect of human bone marrow stromal cells and dermal fibroblasts on angiogenesis. Plast Reconstr Surg 2006;117:829-835

8. Macrin D, Joseph JP, Pillai AA, Devi A. Eminent sources of adult mesenchymal stem cells and their therapeutic imminence. Stem Cell Rev 2017;13:741-756

9. Tabatabaei Qomi R, Sheykhhasan M. Adipose-derived stromal cell in regenerative medicine: a review. World J Stem Cells 2017;9:107-117

10. Cao Y, Gang X, Sun C, Wang G. Mesenchymal stem cells improve healing of diabetic foot ulcer. J Diabetes Res 2017 Mar 12 [Epub]. doi: 10.1155/2017/9328347

11. Zhang Y, Cai J, Zhou T, Yao Y, Dong Z, Lu F. Improved long-term volume retention of stromal vascular fraction gel grafting with enhanced angiogenesis and adipogenesis. Plast Reconstr Surg 2018. doi: 10.197/PRS.0000000000004312

12. Zakhari JS, Zabonick J, Gettler B, Williams SK. Vasculo- 
genic and angiogenic potential of adipose stromal vascular fraction cell populations in vitro. In Vitro Cell Dev Biol Anim 2018;54:32-40

13. Jin E, Chae DS, Son M, Kim SW. Angiogenic characteristics of human stromal vascular fraction in ischemic hindlimb. Int J Cardiol 2017;234:38-47

14. Wang WZ. Microcirculatory response in vivo on local intraarterial infusion of autogenic adipose-derived stem cells or stromal vascular fraction. Plast Reconstr Surg Glob Open 2016. doi: 10.1097/GOX.0000000000001067

15. Bourin P, Bunnell BA, Casteilla L, Dominici M, Katz AJ, March KL, Redl H, Rubin JP, Yoshimura K, Gimble JM. Stromal cells from the adipose tissue-derived stromal vascular fraction and culture expanded adipose tissue-derived stromal/stem cells: a joint statement of the International Federation for Adipose Therapeutics and Science (IFATS) and the International Society for Cellular Therapy (ISCT). Cytotherapy 2013;15:641-648

16. Lee JM, Moon KC, Han SK, Jeong SH, Kim WK. What tissue is formed after graft of adipose-derived stromal vascular fraction cells? J Craniofac Surg 2013;24:636-639

17. Costa M, Cerqueira MT, Santos TC, Sampaio-Marques B, Ludovico P, Marques AP, Pirraco RP, Reis RL. Cell sheet engineering using the stromal vascular fraction of adipose tissue as a vascularization strategy. Acta Biomater 2017;55: $131-143$

18. Lowry D, Saeed M, Narendran P, Tiwari A. The difference between the healing and the nonhealing diabetic foot ulcer: a review of the role of the microcirculation. J Diabetes Sci Technol 2017;11:914-923

19. Lee YN, Kim HS, Kang JA, Han SK. Can macrocirculation changes predict nonhealing diabetic foot ulcers? J Wound Ostomy Continence Nurs 2014;41:430-435

20. Mayrovitz HN, Larsen PB. Functional microcirculatory impairment: a possible source of reduced skin oxygen tension in human diabetes mellitus. Microvasc Res 1996;52:115-126

21. Eleftheriadou I, Tentolouris A, Grigoropoulou P, Tsilingiris D, Anastasiou I, Kokkinos A, Perrea D, Katsilambros N, Tentolouris N. The association of diabetic microvascular and macrovascular disease with cutaneous circulation in patients with type 2 diabetes mellitus. J Diabetes Complications 2019;33:165-170

22. Klonizakis M, Manning G, Lingam K, Donnelly R, Yeung JM. Effect of diabetes on the cutaneous microcirculation of the feet in patients with intermittent claudication. Clin
Hemorheol Microcirc 2015;61:439-444

23. Pan X, You C, Chen G, Shao H, Han C, Zhi L. Skin perfusion pressure for the prediction of wound healing in critical limb ischemia: a meta-analysis. Arch Med Sci 2018;14:481487

24. Ballard JL, Eke CC, Bunt TJ, Killeen JD. A prospective evaluation of transcutaneous oxygen measurements in the management of diabetic foot problems. J Vasc Surg 1995;22:485-490; discussion 490-492

25. Moon KC, Lee JS, Han SK, Lee HW, Dhong ES. Effects of human umbilical cord blood-derived mesenchymal stromal cells and dermal fibroblasts on diabetic wound healing. Cytotherapy 2017;19:821-828

26. Schultz GS, Sibbald RG, Falanga V, Ayello EA, Dowsett C, Harding K, Romanelli M, Stacey MC, Teot L, Vanscheidt W. Wound bed preparation: a systematic approach to wound management. Wound Repair Regen 2003;11 Suppl 1:S1-28

27. Marino G, Moraci M, Armenia E, Orabona C, Sergio R, De Sena G, Capuozzo V, Barbarisi M, Rosso F, Giordano G, Iovino F, Barbarisi A. Therapy with autologous adipose-derived regenerative cells for the care of chronic ulcer of lower limbs in patients with peripheral arterial disease. J Surg Res 2013;185:36-44

28. Lee HC, An SG, Lee HW, Park JS, Cha KS, Hong TJ, Park JH, Lee SY, Kim SP, Kim YD, Chung SW, Bae YC, Shin YB, Kim JI, Jung JS. Safety and effect of adipose tissue-derived stem cell implantation in patients with critical limb ischemia: a pilot study. Circ J 2012;76:1750-1760

29. Argibay B, Trekker J, Himmelreich U, Beiras A, Topete A, Taboada P, Pérez-Mato M, Vieites-Prado A, Iglesias-Rey R, Rivas J, Planas AM, Sobrino T, Castillo J, Campos F. Intraarterial route increases the risk of cerebral lesions after mesenchymal cell administration in animal model of ischemia. Sci Rep 2017. doi: 10.1038/srep40758

30. Carstens MH, Gómez A, Cortés R, Turner E, Pérez C, Ocon $M$, Correa D. Non-reconstructable peripheral vascular disease of the lower extremity in ten patients treated with adipose-derived stromal vascular fraction cells. Stem Cell Res 2017;18:14-21

31. Traktuev DO, Prater DN, Merfeld-Clauss S, Sanjeevaiah AR, Saadatzadeh MR, Murphy M, Johnstone BH, Ingram DA, March KL. Robust functional vascular network formation in vivo by cooperation of adipose progenitor and endothelial cells. Circ Res 2009;104:1410-1420 